\title{
Morphology, performance and attachment function in Corynosoma spp. (Acanthocephala)
}

\author{
Francisco Javier Aznar ${ }^{1 *}$, Jesús Servando Hernández-Orts ${ }^{2}$ and Juan Antonio Raga ${ }^{1}$
}

\begin{abstract}
Background: Functional inference on the attachment of acanthocephalans has generally been drawn directly from morphology. However, performance of structures is often non-intuitive and context-dependent, thus performance analysis should be included whenever possible to improve functional interpretation. In acanthocephalans, performance analysis of attachment is available only for Acanthocephalus ranae, a species that solely relies on the proboscis to attach. Here we compare body morphology and muscle arrangement in 13 species of Corynosoma, which use their spiny body as a fundamental holdfast. A basic performance analysis using live cystacanths of two representative species is also provided.

Methods: Adults of 13 Corynosoma spp. were obtained from 11 marine mammal species. Specimens were cut and carefully cleaned to examine muscle arrangement through light and scanning electron microscopy. Live cystacanths of C. australe and C. cetaceum were selected for performance analysis. Video records of evagination-invagination cycles of the proboscis were obtained and analysed with a video editor.

Results: The basic arrangement of proboscis retractors, trunk circular and longitudinal muscles, neck retractors and receptacle retractors, was conserved in all Corynosoma species. Interspecific variability was found in the relative development of disk muscles: minimum in C. enhydri, maximum in C. cetaceum; the distal insertion of the ventral neck retractor: ventro-lateral in C. cetaceum, C. hamannni and C. pseudohamanni and ventral in the other species; and the distal insertion of the receptacle retractors: more proximal in species with a longer hindtrunk. Performance analysis indicated striking similarities to that described for A. ranae except that (i) the foretrunk bends ventrally during the evagination-invagination cycles of the proboscis; (ii) disk muscles can flatten the tip of the foretrunk regardless of these cycles; and (iii) the receptacle bends ventrally and is driven to the hindtrunk by coordinated action of receptacle retractors.

Conclusions: Species of Corynosoma are able to use up to six holfast mechanisms. Attachment relies on a similar performance to that described for A. ranae. However, structural ventral bending of an inflated, spiny foretrunk, with a parallel re-arrangement of foretrunk muscles, have generated unexpected novel functions that make attachment extremely effective in species of Corynosoma. Interspecific variability in trunk shape and muscle arrangement grossly correlates with the rheological conditions each species experiences in their microhabitats within the gut of marine mammals.
\end{abstract}

Keywords: Acanthocephala, Polymorphidae, Corynosoma, Attachment, Performance, Muscle, Ecomorphology

\footnotetext{
* Correspondence: francisco.aznar@uv.es

${ }^{1}$ Instituto Cavanilles de Biodiversidad y Biología Evolutiva, Parque Científico,

Universidad de Valencia, Catedrático José Beltrán 2, 46980, Paterna, Valencia,

España

Full list of author information is available at the end of the article
}

(c) The Author(s). 2018 Open Access This article is distributed under the terms of the Creative Commons Attribution 4.0 International License (http://creativecommons.org/licenses/by/4.0/), which permits unrestricted use, distribution, and reproduction in any medium, provided you give appropriate credit to the original author(s) and the source, provide a link to the Creative Commons license, and indicate if changes were made. The Creative Commons Public Domain Dedication waiver (http://creativecommons.org/publicdomain/zero/1.0/) applies to the data made available in this article, unless otherwise stated. 


\section{Background}

From a functional and evolutionary perspective, the morphology of most parasites is largely driven by the need for an effective attachment to their hosts. Acanthocephalans in particular, have developed a proboscis armed with hooks that anchors to the gut of their definitive vertebrate hosts [1]. Many species also use secondary mechanisms that may play an even more prominent role as attachment devices $[2,3]$.

Functional inferences on the attachment of acanthocephalans have generally been drawn directly from their morphology. For instance, in a series of recent studies, Herlyn \& Ehlers [4], Herlyn [5], and Herlyn \& Taraschewski [6] provided painstaking descriptions of the muscular apparatus of several acanthocephalan species, and made basic inferences on their function and evolution. However, the performance of any structure, which is the crucial link between its morphology and function, is often non-intuitive and context-dependent $[7,8]$. As far as we are aware, there is a single acanthocephalan species for which a complete account of its attachment performance has been carried out. Hammond [9-11] used live detached specimens of Acanthocephalus ranae (Schrank, 1788) to describe cycles of evagination-invagination of the proboscis as well as the mechanisms that worms actually use to anchor to the intestinal wall of toads (see Additional file 1: Data S1 and Additional file 2: Figure S1 for a brief description of the morphology, performance and attachment function in A. ranae). This approach allowed this author to unveil details of the attachment function that could have easily been overlooked from examination of morphology alone.

Species of Corynosoma Lühe, 1904 (Palaeacanthocephala: Polymorphidae) infect a wide array of marine mammal species, and more rarely marine birds, worldwide [12]. The body morphology of this group is peculiar: the foretrunk is inflated and ventrally bent, giving the animals a pipe-shaped appearance. Furthermore, the ventral side of the trunk is covered, to a variable extent, with spines (Fig. 1). Aznar et al. [3] investigated the attachment function of $C$. cetaceum Johnston \&

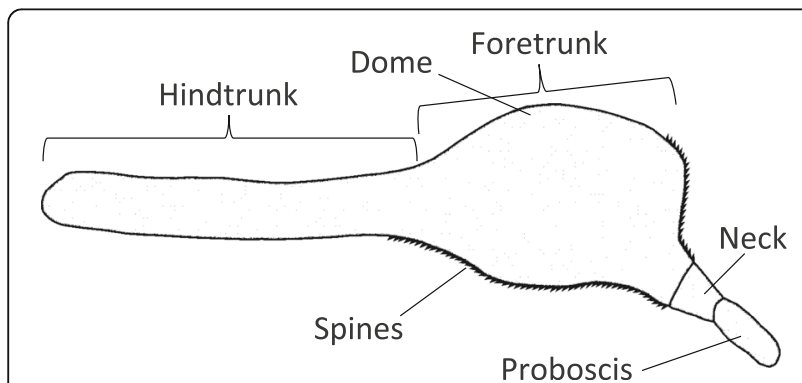

Fig. 1 Schematic drawing of the external morphology of Corynosoma spp.
Best, 1942 based on a detailed description of external morphology and foretrunk musculature. More recently, Aznar et al. [12] provided a basic description of foretrunk muscles in additional species of Corynosoma and proposed a general attachment mechanism for species of this genus, following previous insight from Van Cleave [2]. In essence, species of Corynosoma use the flattened, spiny foretrunk as a very efficient device that assists the proboscis to adhere to the gut wall, but are also able to put the ventral hindtrunk into contact with the substratum, reinforcing attachment.

In this paper, we investigate the attachment function in species of Corynosoma using a more comprehensive approach. First, we describe the foretrunk musculature in 13 species encompassing the widest morphological variation in a genus with $c .31 \mathrm{spp}$. described $[12,13]$. This information is, for the most part, new for all species except $C$. cetaceum. However, it is important to stress from the outset that our approach is functional and, therefore, we will not pay attention to subtle differences in muscle arrangement that are more meaningful in an evolutionary context (see, e.g. [6]). Secondly, we use live cystacanths of two species to explore the link between muscle arrangement and performance. Cystacanths of Corynosoma exhibit the same morphology as adults except that they are sexually immature [14], but their anatomy is more visible by transparency. We recorded a range of body movements, including cycles of evagination-invagination of the proboscis, to infer the attachment mechanisms. Finally, we combine morphological and performance data to understand how species of Corynosoma actually attach, and to explore the relationship between interspecific morphological variability and microhabitat selection within the host.

\section{Methods}

\section{Comparison of foretrunk musculature}

Adult individuals of 13 Corynosoma spp. were obtained from 11 marine mammal species around the world based on specific sampling or requests to museums or particular collections. Details of host identity, locality of collection, and number of specimens examined are shown in Table 1. Most species came from old opportunistic collections and information on specific sampling localities was not available. Specimens had all been collected from stranded or by-caught hosts. Worms were found dead, removed from the intestine or the stomach, washed in saline, and fixed in $70 \%$ ethanol at room temperature.

For examination of foretrunk muscles we followed the methodology described in Aznar et al. [3]. Specimens were cut with a razor blade through the transversal or mid-sagittal plane, carefully cleaned to reveal the muscular arrangement, and stained with eosine before examination under a stereomicroscope. Drawings were made with the aid of a drawing tube. Pieces of 
Table 1 Collection data for adult specimens of Corynosoma spp. examined in this study

\begin{tabular}{|c|c|c|c|c|}
\hline \multirow[t]{2}{*}{ Species } & \multirow[t]{2}{*}{ Host } & \multicolumn{2}{|c|}{ No. of worms } & \multirow[t]{2}{*}{ Locality } \\
\hline & & Males & Females & \\
\hline C. australe Johnston, 1937 & Otaria flavescens Shaw & 10 & 10 & Off Puerto Madryn (Argentina) \\
\hline C. bullosum (Linstow, 1892) & Mirounga leonina $(\mathrm{L})$. & 5 & 5 & Antarctica \\
\hline C. caspicum Golvan \& Mokhayer, 1973 & Pusa caspica Gmelin & 10 & 10 & Caspian Sea \\
\hline C. cetaceum Johnston \& Best, 1942 & Pontoporia blainvillei (Gervais \& d'Orbigny) & 10 & 10 & Off Necochea (Argentina) \\
\hline C. enhydri Morozov, 1940 & Enhydra lutris (L.) & 10 & 10 & Off British Columbia (Canada) \\
\hline C. hamanni Linstow, 1892 & Hydrurga leptonyx (Blainville) & 10 & 10 & Antarctica \\
\hline C. magdaleni Montreuil, 1958 & Pusa hispida Schreber & 5 & 5 & Lake Saimaa (Finland) \\
\hline C. pseudohamanni Zdzitowiecki, 1984 & Hydrurga leptonyx (Blainville) & 3 & 3 & Antarctica \\
\hline C. semerme (Forssell, 1904) & Phoca vitulina $\mathrm{L}$. & 5 & 5 & Off Germany \\
\hline C. strumosum (Rudolphi, 1802) & Pusa hispida Schreber & 10 & 10 & Off Russia \\
\hline C. validum Van Cleave, 1953 & Odobenus rosmarus (L.) & 10 & 10 & Off Russia \\
\hline C. villosum Van Cleave, 1953 & Eumetopias jubatus (Schreber) & 10 & 10 & Bering Sea \\
\hline C. wegeneri Heinze, 1934 & Pusa hispida Schreber & 10 & 10 & Off Russia \\
\hline
\end{tabular}

tegument were also stained with eosin and observed under light microscope (100-400x). To investigate structural details, some specimens were dehydrated through an ethanol series, critical point-dried, and coated with a gold-palladium alloy to a thickness of $250 \mathrm{~nm}$. Specimens were then examined with a Hitachi 4100FE scanning electron microscope operating at $10-20 \mathrm{kV}$.

\section{Performance}

We adopted the methodology used by Hammond [10] to examine worm movements with a reasonable view of internal structures. A total of 10 cystacanths of $C$. australe were collected from a sample of 42 gutted Argentinean hakes, Merluccius hubbsi Marini, captured with fishing lines in the San Matías Gulf, Argentina $\left(40^{\circ} 50^{\prime}-42^{\circ} 15^{\prime} \mathrm{S}, 63^{\circ} 45^{\prime}-65^{\circ} 00^{\prime} \mathrm{W}\right)$ from June to November 1997. Hake size ranged from 57 to $78 \mathrm{~cm}$ (mean \pm standard deviation, $67.5 \pm 5.7 \mathrm{~cm}$ ). The fish were air freighted and imported fresh by a Spanish supermarket company. The hake were examined 3 to 4 days after capture. A total of 14 cystacanths of $C$. cetaceum were collected from 5 flounders, Xystreurys rasile (Jordan) collected by Argentine hake trawlers in waters of the central Patagonian shelf, Argentina $\left(47^{\circ} 00^{\prime}-47^{\circ} 19^{\prime} \mathrm{S}\right.$, $\left.61^{\circ} 59^{\prime}-64^{\circ} 25^{\prime} \mathrm{W}\right)$ in March 2007. Flounder size ranged from 32.6 to $36.9 \mathrm{~cm}(34.4 \pm 1.7 \mathrm{~cm})$ and were examined fresh 4 to 5 days after capture.

Live cystacanths were removed from fish mesenteries and put in a Petri dish with $0.9 \%$ saline. Active worms deployed a range of movements including frequent evagination-invagination cycles of the proboscis apparatus. We recorded worm movements with a Sony DSC-S60 camera connected to a stereomicroscope (20-40x) using transmitted light. Videos were then edited with the open source VLC Media Player 2.0.6.

\section{Results \\ Morphology}

For comparative purposes, we follow Hammond [10] for muscle nomenclature. However, when necessary we also provide, in brackets, the terminology used by Aznar et al. $[3,12]$ to ensure equivalence.

\section{Trunk muscles}

Trunk circular muscles (TCs) [transversal muscles] Layer of circular muscles lining the trunk wall, being arranged as transversal circular bands. Bands usually single and roughly symmetrical in cylindrical parts, but branching off on the dome (Fig. 1) to cover the additional surface produced by the curvature and inflation of the dorsal foretrunk.

Trunk longitudinal muscles (TLs) Most of them expanding toward the centre of the disk, leaving lines of contact only with the foretrunk wall, and becoming organized as semi-tubular bundles, collectively named as disk muscles (Ds) [3]. Ds arranged singly or in tightly packed groups (Fig. 2a) with the appearance of "columns" on a sagittal view (Fig. 2b). Four recognizable groups, i.e. D1, D2, D3 and D4 [3] (Figs. 2 and 3).

Comments The basic arrangement in four groups is conserved in all Corynosoma species, but the radial development of D3 and D4 is rather variable (Fig. 3), being minimal in C. enhydri and maximal in C. cetaceum (Fig. 2a). The greater relative development of these muscles appears 


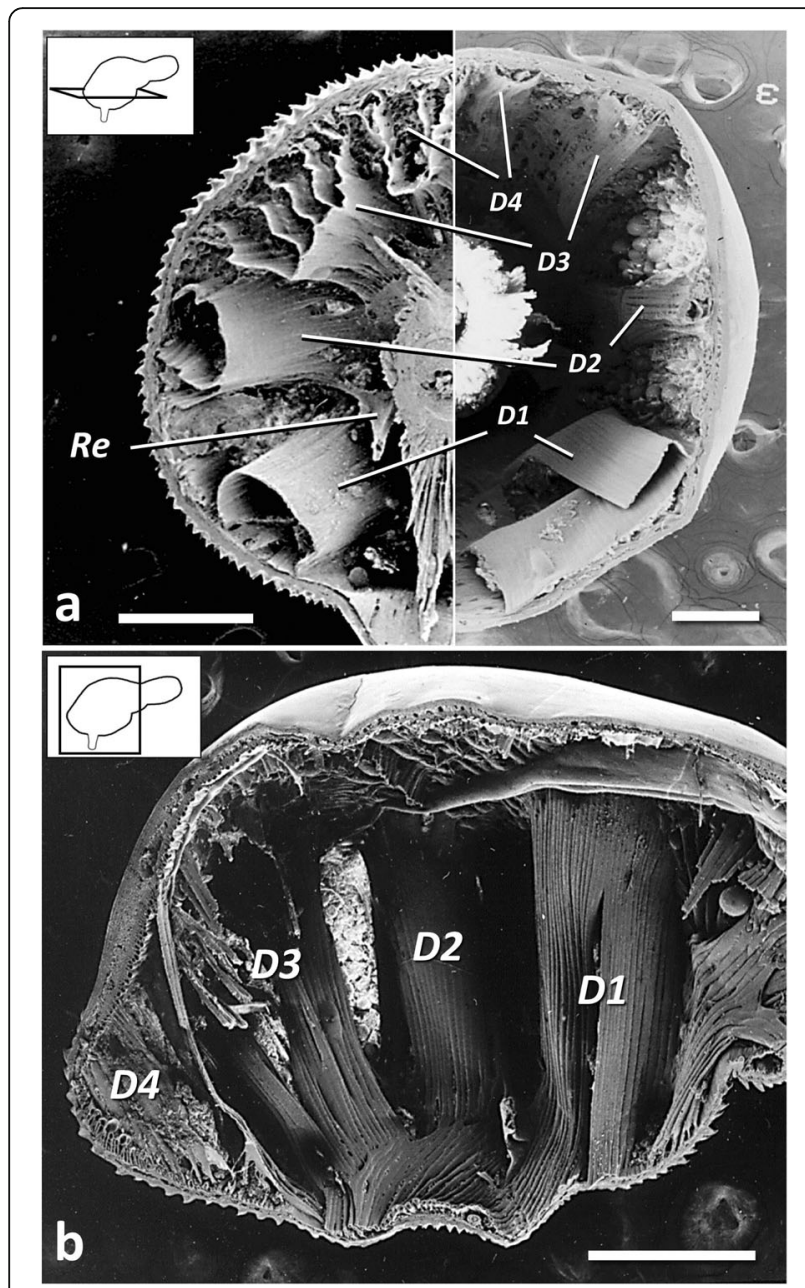

Fig. 2 Disk muscles in Corynosoma spp. a Transversal view of half foretrunk of female C. cetaceum (left) and female C. enhydri (right). b Saggital view of female C. cetaceum. Scale-bars: $0.5 \mathrm{~mm}$. Abbreviations: D1-D4, disk muscles 1-4 (abbreviated as in Aznar et al. [3]); $\mathrm{Re}$, retinaculum

to be associated with a more centred position of the proboscis coupled with a wider transversal expansion of the proximal half of the disk, such as it is observed in C. cetaceum, C. hamanni and C. pseudohamanni, and to a lesser extent, $C$. validum (Fig. 3). Also, the D1 is arranged as a semi-folded sheet in all species except C. hamanni, C. pseudohamanni and especially C. cetaceum, in which folding progresses to form a nearly closed tube (Fig. 2a).

\section{Neck retractor muscles (NRs)}

With dorsal and ventral bundles. Dorsal portion divided into two large bundles (DNRs) that insert around the neck except its posterior part, fanning out to attach longitudinally along the dorsal dome (Figs. 4 and 5), and also experiencing a substantial transversal expansion (Fig. 4a). Ventral neck retractor (VNR) single, inserting in the posterior portion of the neck, fanning

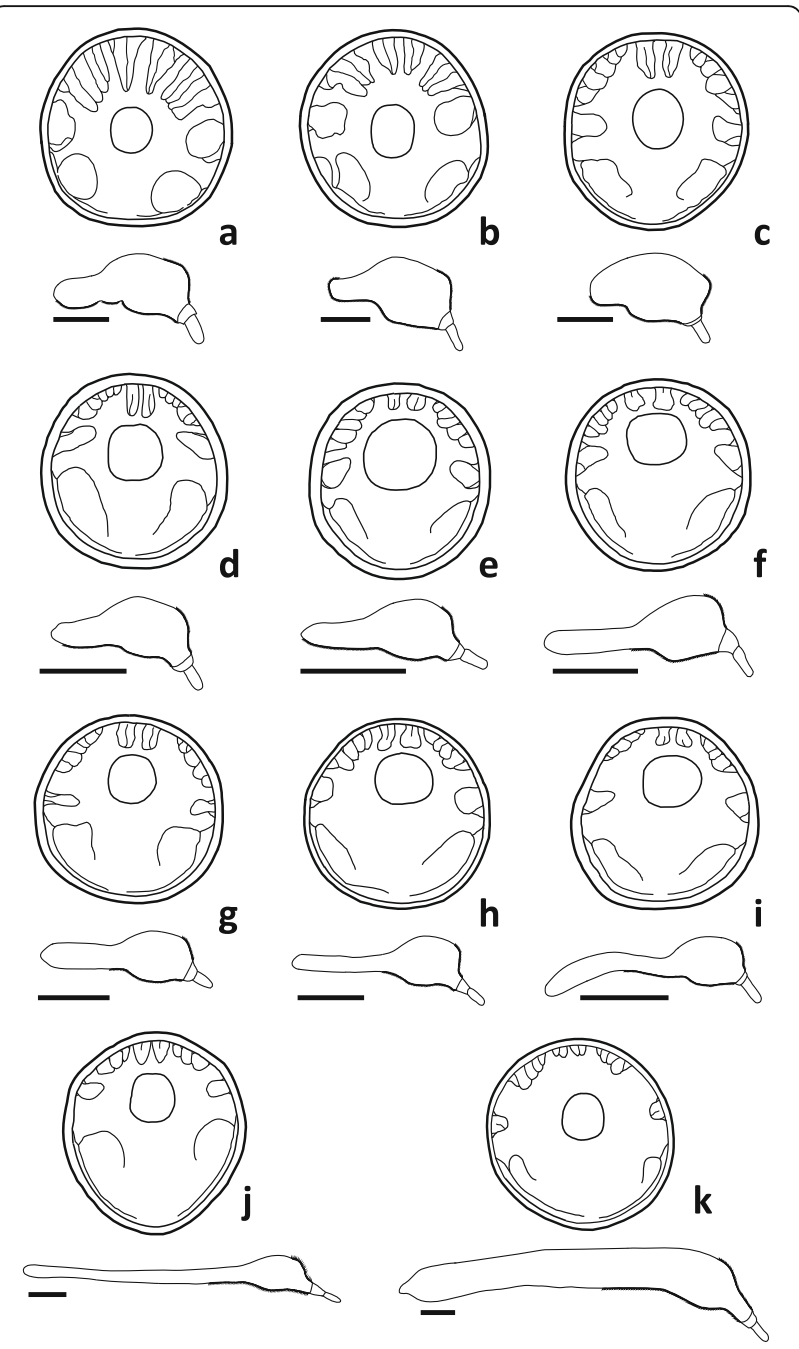

Fig. 3 Lateral trunk view and schematic transversal view of disk muscles in females of Corynosoma spp. a C. cetaceum. b C. hamanni / C. pseudohamanni. c C. validum. d C. australe. e C. semerme. f C. caspicum. g C. villosum. h C. wegeneri. i C. strumosum / C. magdaleni. j C. bullosum. k C. enhydri. Scale-bars: $2 \mathrm{~mm}$

out to attach on the ventral, or ventro-lateral, part of the hindtrunk (Fig. 4a, b). Lemnisci not associated to NRs in any species.

Comments The basic arrangement of DNRs and the VNR is similar in all Corynosoma species. However, the distal insertion of VNR can reach far beyond the dome in C. australe, C. enhydri and males of C. validum (Fig. 5). The distal insertion of the VNR is ventral in most species of Corynosoma, but the distal attachment experiences a great expansion onto the lateral hindtrunk in C. hamanni, C. pseudohamanni and especially C. cetaceum (Figs. 4 and 5). The lemnisci typically arise in the external side of the DNRs (Fig. 4a). However, in C. enhydri, the lemnisci are curved and embrace the posterior part of the DNRs on both sides. 


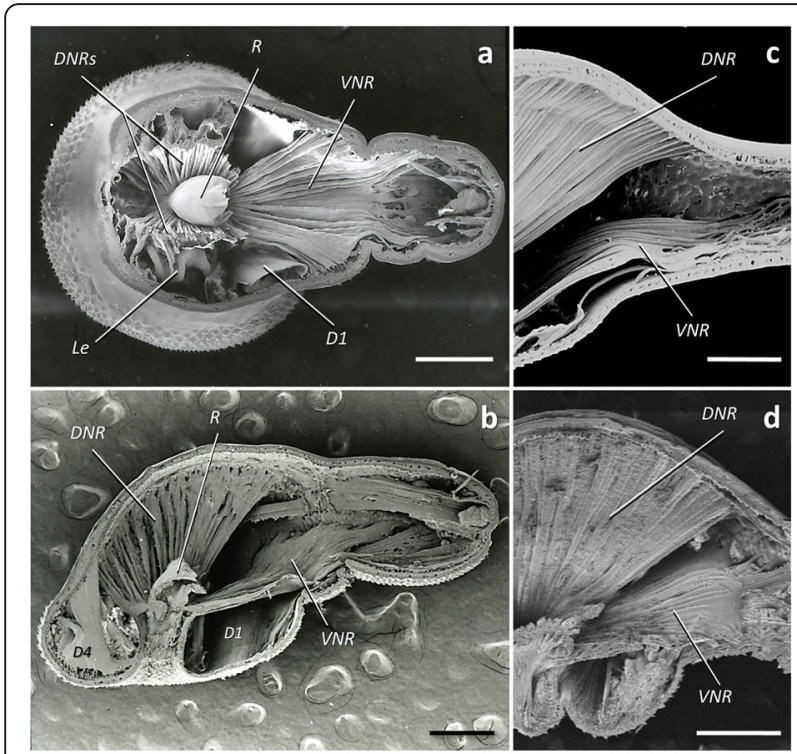

Fig. 4 Neck retractor muscles in Corynosoma spp. a Dorsal view of female $C$. cetaceum. $\mathbf{b}$ Lateral view of female $C$. cetaceum cut through mid-sagittal plane. Note that the receptacle is cut in both pictures to better view muscle arrangement. c Detail of distal insertion of neck retractors in female $C$. wegeneri. $\mathbf{d}$ Detail of distal insertion of neck retractors in female C. hamanni. Scale-bars: $0.5 \mathrm{~mm}$. Abbreviations: D1, D4, disks muscles 1, 4; DNR(s), dorsal neck retractor(s); Le, lemniscus; $R$, receptacle; VNR, ventral neck retractor

\section{Proboscis retractor muscles (PRs)}

Several bundles of longitudinal muscles running from the tip of the proboscis to the bottom of the proboscis receptacle. No further, more detailed examination was carried out in any species.

\section{Receptacle retractor muscles (RRs)}

Double, with thin dorsal and ventral bundles (Fig. 5). Proximal insertion at the tip of the receptacle and distal insertion at roughly the same point of the dorsal (DRR) or ventral (VRR) mid-sagittal plane of the hindtrunk (Fig. 5).

Comments The distal insertion of the RRs is highly variable among species of Corynosoma. Five species lack sexual dimorphism in body shape and have a long hindtrunk relative to foretrunk, i.e. C. bullosum, C. enhydri, C. magdaleni, C. strumosum and $C$. wegeneri. In these species, except $C$. enhydri, the distal insertion of RRs occurs anterior to mid-hindtrunk (Fig. 5). In C. enhydri, and in the species with a medium-sized hindtrunk (i.e. C. villosum, C. caspicum, C. semerme and C. australe), the distal insertion of RRs is at the mid-hindtrunk in both sexes (Fig. 5). Finally, 4 species (i.e. C. cetaceum, C. hamanni, C. pseudohamanni and $C$. validum) exhibit clear dimorphism in body shape, with females having a shorter hindtrunk. The distal insertion of RRs is at the mid-hindtrunk (males) or distal hindtrunk (females) (Fig. 5).

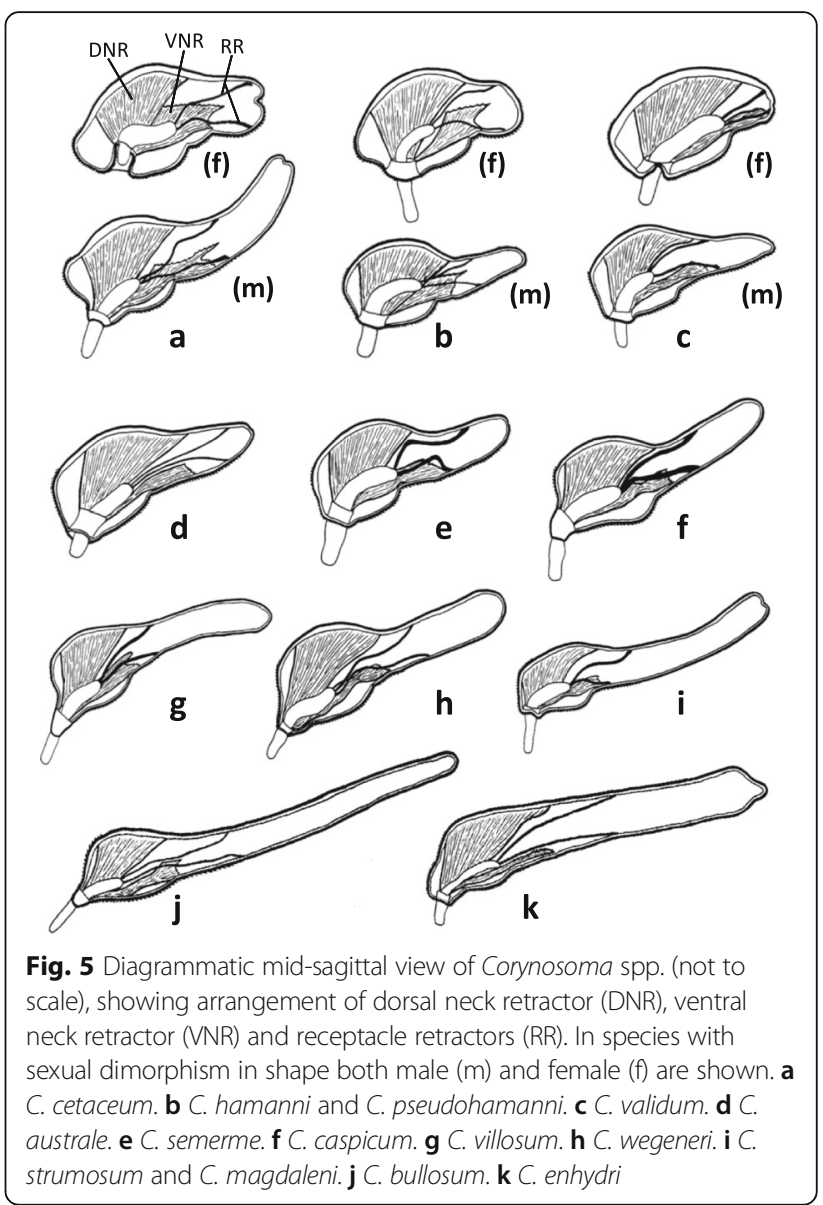

\section{Performance}

\section{Evagination-invagination of the proboscis}

A cycle of evagination-invagination of the proboscis in cystacanths of C. australe is shown in Fig. 6. The cycle is similar in C. cetaceum (not shown). The cycle starts with the presoma withdrawn within the body cavity, and the proboscis within the proboscis receptacle (Fig. 6a). Then, there is a strong contraction of the TCs on the hindtrunk; contraction is so strong that the hindtrunk tegument becomes longitudinally wrinkled, perhaps pushing the fluid of the lacunar system forwards (Figs. 6b-d and 7a, b). Such contraction provokes: (i) an elongation and reduction in diameter of the hindtrunk (Fig. 6b); (ii) an increase of internal pressure, which squeezes fluid forwards (fluid movement can be observed in Additional file 3: Video S1, Additional file 4: Video S2, Additional file 5: Video S3), pushing the proboscis receptacle forwards and forcing the presoma to unfold (Figs. $6 \mathrm{c}, \mathrm{d}$ and $7 \mathrm{~b}, \mathrm{c}$ ); and (iii) a downward bending of the foretrunk as a passive effect of an increased hydrostatic pressure on the inflated, ventrally curved foretrunk (Figs. 6b and 7a). Unfolding requires that the NRs and RRs are relaxed, but the Ds may or may not contract to flatten the foretrunk, 


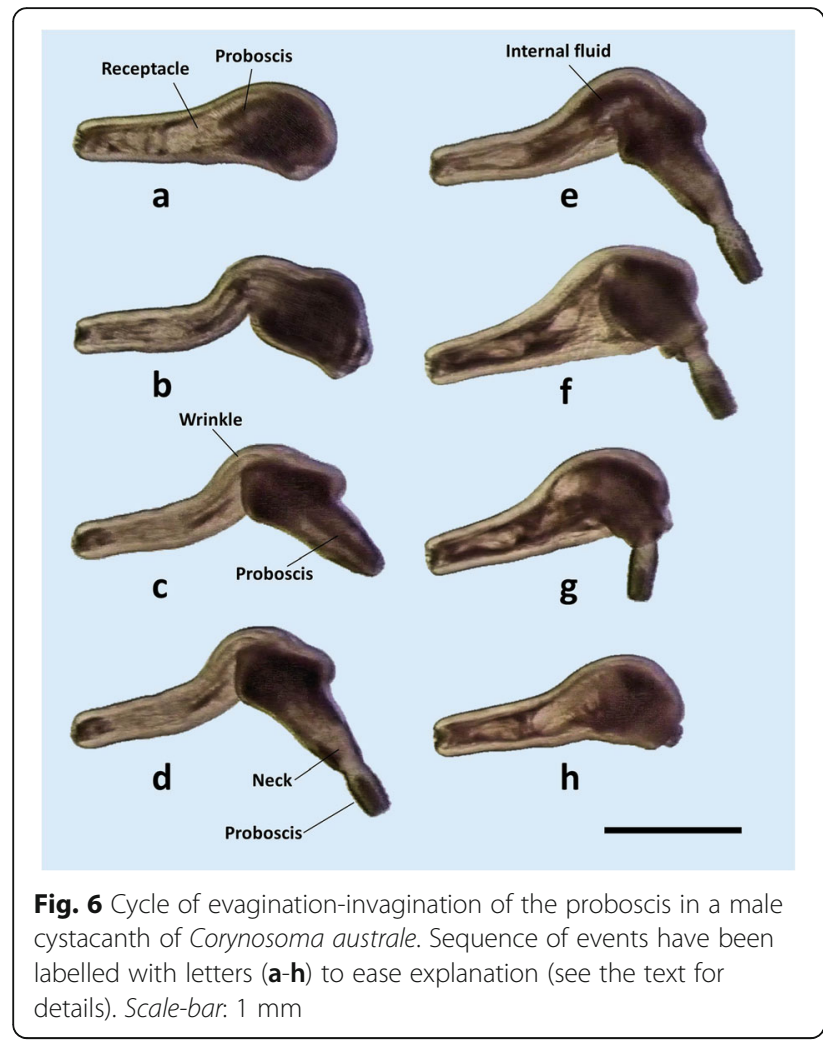

forming the disk (Fig. 7, Additional file 3: Video S1, Additional file 4: Video S2, Additional file 5: Video S3). During the unfolding of the proboscis apparatus, the circular muscles of the receptacle also contract, evaginating, fully or partially, the proboscis (Fig. 6d, Additional file 3: Video S1, Additional file 4: Video S2, Additional file 5: Video S3).

Once the proboscis is everted, the TCs relax, and the hyper-pressurized fluid accumulated in the foretrunk moves passively backwards, reaching even the posterior tip of the hindtrunk (Fig. 6e, f). The NRs then contract, invaginating the proboscis apparatus; the receptacle is driven to an inner position within the hindtrunk by the coordinated contraction of dorsal and ventral RRs, which ventrally bend the receptacle once it contacts the dome (Figs. $6 \mathrm{f}-\mathrm{h}$ and $7 \mathrm{~d}-\mathrm{f}$ ). The proboscis can remain everted or be invaginated by the contraction of the PRs (Additional file 3: Video S1, Additional file 4: Video S2, Additional file 5: Video S3).

\section{Disk formation and hindtrunk movement}

The disk is formed by the contraction of Ds, which can flatten the tip of the foretrunk independently of the evagination-invagination cycle of the proboscis (Fig. 7, Additional file 3: Video S1, Additional file 4: Video S2, Additional file 5: Video S3). Deep contraction of the inner portion of Ds results in the

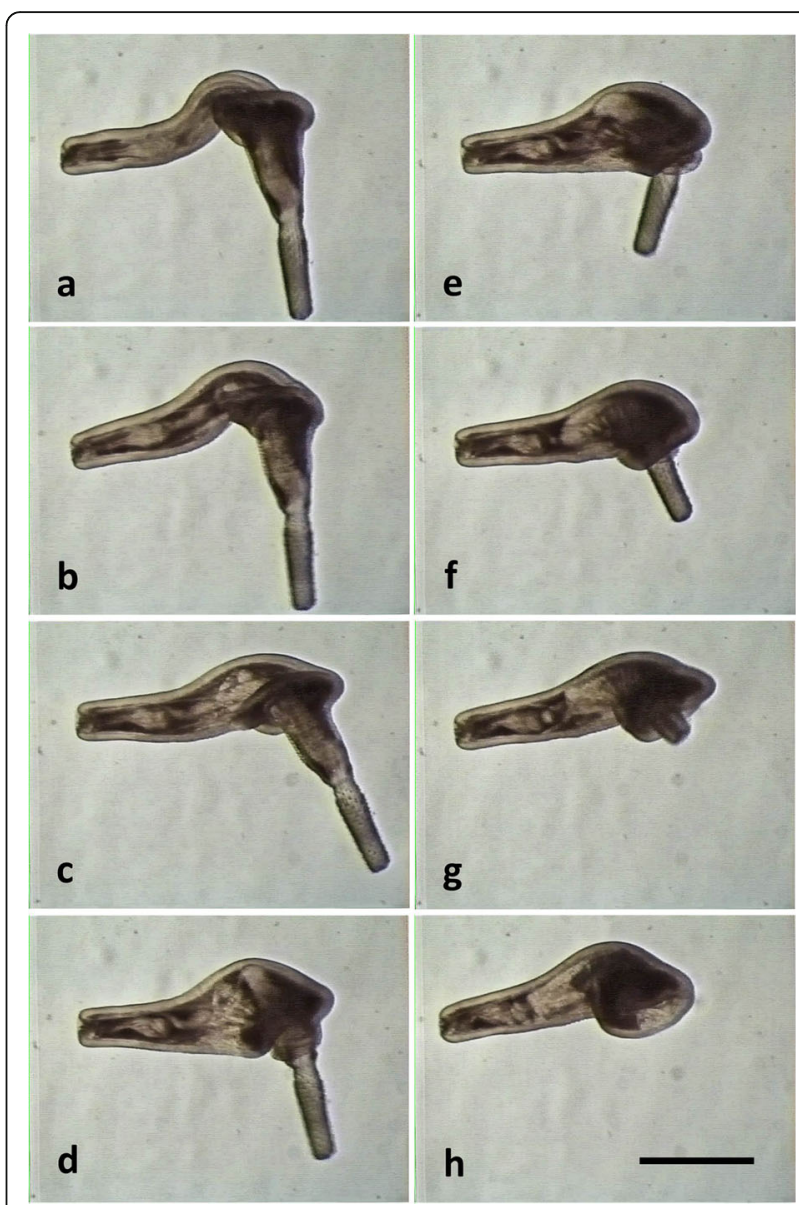

Fig. 7 Details of disk formation, proboscis eversion and bending of the proboscis receptacle in a male cystacanth of Corynosoma australe. Sequence of events have been labelled with letters (a-h) to ease explanation (see the text for details). Scale-bar: $1 \mathrm{~mm}$

formation of a circular inward fold of tegument (Fig. 8). In contrast, the TCs of the foretrunk can generate a tubular invagination of the foretrunk tip when the presoma is withdrawn within the trunk (Fig. 7f-h, Additional file 3: Video S1, Additional file 4: Video S2, Additional file 5: Video S3). The local, antagonistic action of Ds and TCs, mediated by the hydrostatic skeleton, can generate an impressive variety of movements and shapes of the disk (Additional file 3: Video S1, Additional file 4: Video S2, Additional file 5: Video S3 and Additional file 6: Video S4).

In $C$. australe, the ventral (spiny) side of the hindtrunk becomes aligned with the disk during the invagination-evagination cycle of the proboscis (Figs. 6 and 7). However, C. cetaceum can move the hindtrunk downwards by a strong contraction of the VNR. This contraction shortens and ventrally tilts the hindtrunk, producing a deep fold on its ventral side (Fig. 8, Additional file 6: Video S4). 


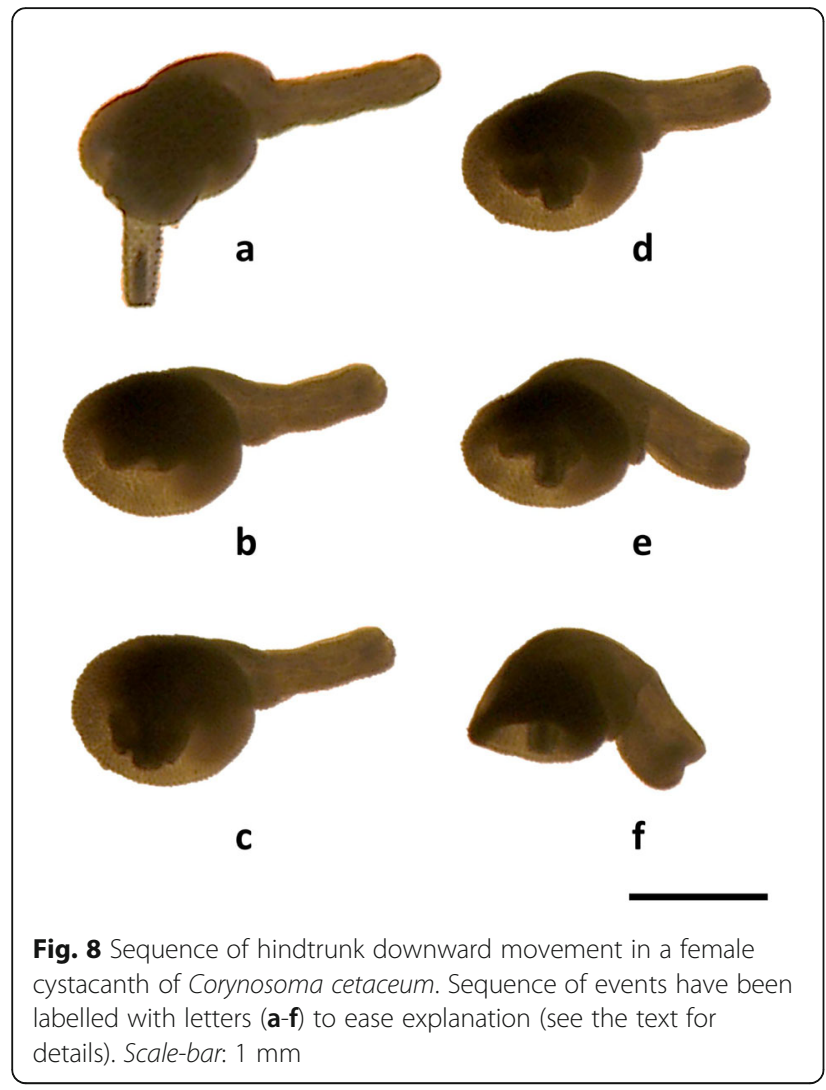

\section{Discussion}

Holdfast mechanisms in Corynosoma spp.

According to the above evidence, we suggest that the attachment of Corynosoma spp. to their hosts relies on the interplay of several mechanisms (Fig. 9). First, the proboscis can be withdrawn and anchored to the gut wall. In A. ranae, Hammond [11] noted that the proboscis is fully everted only when the animal firstly engages in the mucosa, but not when the worm is fully attached. Apparently, full evagination helps prevent the newly recruited worms from being expelled when they attempt first (re)attachment. In C. australe and C. cetaceum we observed both partial and complete eversion of the proboscis during cycles of invagination-evagination. Likewise, in fully attached individuals of Corynosoma spp. there are observations of worms with the proboscis fully [15] or partially [16] everted. It is therefore possible that the relatively long proboscis typical of Corynosoma spp. (see references in Aznar et al. [12]) functions as a versatile attachment structure in hosts with intense peristalsis [14].

Once the proboscis penetrates the gut wall and engages in the tissue, contraction of the DNRs can pull the foretrunk against the substratum. This mechanism is similar to that described for $A$. ranae $[10,11]$ but it is far more effective in Corynosoma. The structural bending of the foretrunk allows a spectacular development of
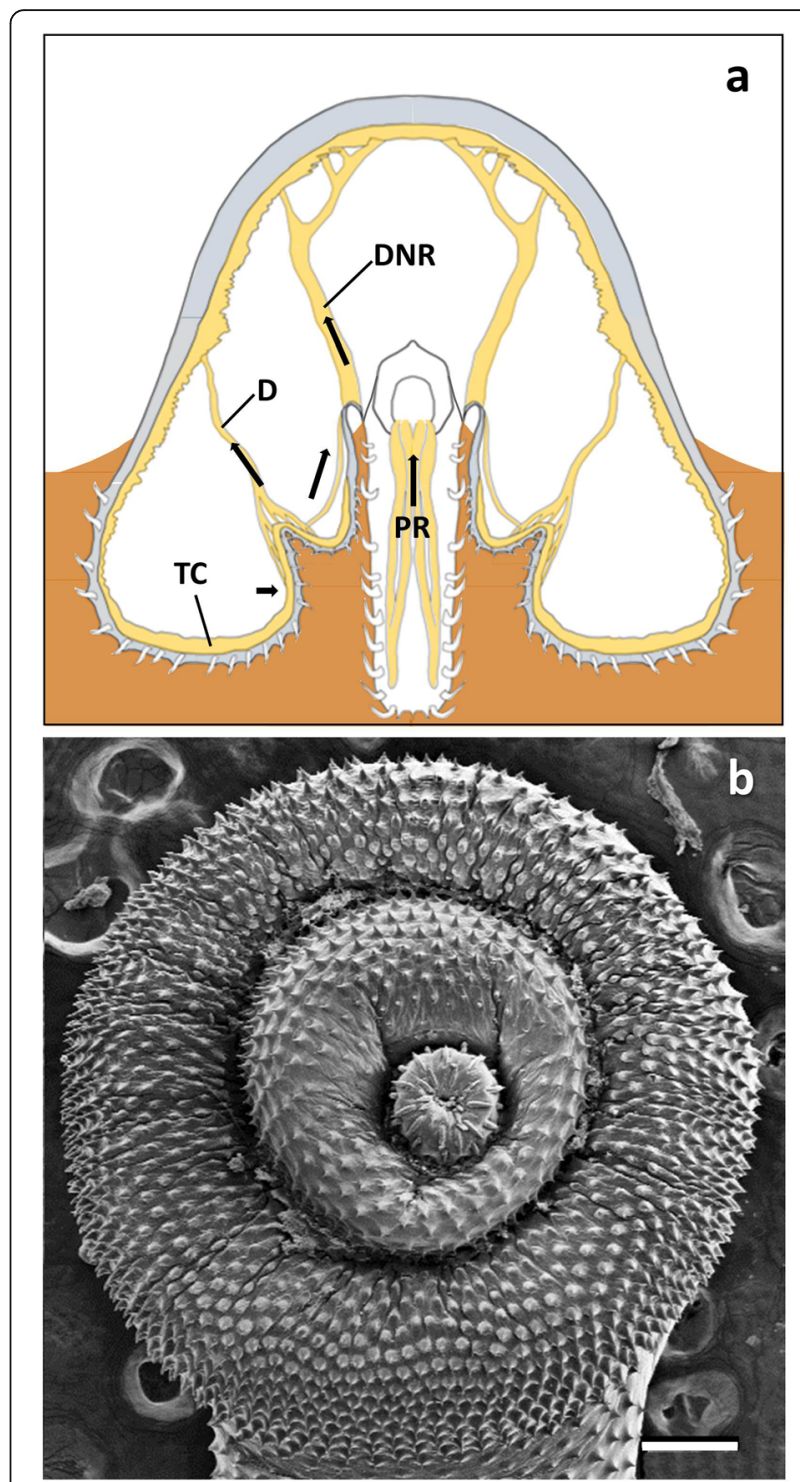

Fig. 9 Attachment mechanisms in Corynosoma spp. a Frontotransversal view of foretrunk of a female $C$. cetaceum, showing major foretrunk muscles and lines of contraction (re-drawn from Aznar et al. [3]). $\mathbf{b}$ Ventral view of the disk in a female C. hamanni. Abbreviations: D, disk muscle; DNR, dorsal neck retractor; PR, proboscis retractor; TC, trunk circular muscles

the DNRs, which can generate a strong reaction force perpendicular to the substratum $[3,12]$. Also, the tip of the foretrunk is flattened, thus providing a greater surface of contact with the gut wall, with spines reinforcing adherence (Fig. 9b). Moreover, the host's tissue is so strongly pulled upwards by the DNRs that a crater is frequently formed during deep attachment $[2,16]$. This elevation of the substratum often traps host tissue between the hooks of the proboscis and the spines on the opposite disk wall, "...as though staples had been applied" on it [2] (Fig. 9b). The crater also increases resistance to horizontal drag and can be embraced by the circular muscles 
of the foretrunk to reinforce adherence (Additional file 3: Video S1, Additional file 4: Video S2, Additional file 5: Video S3 and Additional file 6: Video S4).

Disk muscles, when contracted strongly, can also create a second inward fold that also 'sucks' and traps host tissue (Fig. 9b). If such a process is combined with contraction of circular muscles in the hindtrunk, and relaxation in the foretrunk, the net effect should also be an expansion of the disk border. In deeply attached worms, this expansion would produce a 'wedge' effect against the gut wall because the disk is literally buried in the mucosa ([16]; F.J. Aznar, unpublished observations). Not surprisingly, disk spines are larger on the border than anywhere else on the disk [17].

Finally, structural bending of the trunk in Corynosoma spp. also allows the hindtrunk to contact the substratum in fully attached worms. In fact, all species have developed a ventral field of spines of variable extension that further increases worm's adherence [3, 12]. Structural bending also brings about a re-arrangement of the ventral bundles of the neck retractors, i.e. the VNR, which could generate up-and-down movements of the hindtrunk depending on the relative position of the proximal and distal insertion. If the proximal insertion is lower (e.g. when the neck is at least partly evaginated) VNR contraction would generate an upward torque; if it is at the same level (e.g. when the neck is deeply invaginated) contraction would produce a downward torque (Additional file 6: Video S4). Upward and downward movements of the hindtrunk are potentially related with at least two functions, i.e. copula, and attachment of the hindtrunk, respectively $([3,17,18]$, see below).

\section{Interspecific variability}

The 13 species of Corynosoma included in this study encompass the widest variation in body morphology found within this genus. Trunk size differed by an order of magnitude between the smallest (C. australe and $C$. semerme) and the largest (C. bullosum and $C$. enhydri) species [17] (Fig. 3). Furthermore, there were species with very stout bodies and a short hindtrunk (e.g. females of C. cetaceum, C. hamanni, C. pseudohamanni and especially $C$. validum) and species with slender bodies and a long hindtrunk (e.g. C. strumosum and C. bullosum). Regardless of this variation, the basic arrangement of foretrunk muscles appeared to be conserved in all species and, at the coarse level of analysis we carried out, interspecific differences were found only in three elements with potential functional significance, i.e. the distal insertion of RRs, the transversal expansion of Ds, and the lateral expansion of the VNR. Of course, a more detailed comparison of muscular anatomy (see, e.g. [6]) could reveal further and more subtle interspecific differences in performance and function.

Differences in the distal insertion of RRs are likely related to the role of these muscles in driving the receptacle to a precise position within the hindtrunk when the proboscis apparatus retracts. The receptacle must be bent backwards, requiring a coordinated contraction of the RRs. Apparently, this is possible if the distal insertion of these muscles occurs at a specific point from the dome (Fig. 5, Additional file 5: Video S3 and Additional file 6: Video S4). Therefore, the distal insertion of the RRs should be found at variable points depending on the length of the hindtrunk. This is nicely illustrated by species with sexual dimorphism in body shape: males with a longer hindtrunk than their females exhibit a more anteriad insertion of the RRs (Fig. 5).

There was also a variable degree of transversal development of Ds, especially D3 and D4, being minimal in C. enhydri and maximal in C. cetaceum. A greater development of Ds allows the worms to flatten a higher portion of the foretrunk, but also moves the neck and proboscis onto a more centred position on the disk (Fig. 3). Interestingly, in C. cetaceum, C. hamanni and C. pseudohamanni, the inward secondary folding that is generated by the Ds results in a complete ring (Fig. 9b; see also figure 1a in Ionita et al. [19]), whilst in species with a more eccentric placement of the neck, only a posterior semi-circular fold can be formed due to space limitation for D3 and D4 (see figure 1c, d in Ionita et al. [19]).

Corynosoma cetaceum, C. hamanni and C. pseudohamanni also suffer significant lateral expansion of the VNR. At least in females of C. cetaceum, the VNR assists the animal in performing a downward movement to attach a relatively thick and short hindtrunk $[3,17,18]$. During the process, the hindtrunk somewhat shortens due to ventral folding, and the whole ventral spiny surface contacts the substratum ([17], Additional file 6: Video S4). In C. hamanni and C. pseudohamanni, the hindtrunk is also short and wholly covered by spines, thus one could postulate a similar performance of the VNR. However, why the VNR is less developed in other species is intriguing, particularly in the case of $C$. validum whose females exhibit a ball-like body shape [20]. In species with a very small body size and a fully-spined hindtrunk, i.e. C. australe and C. semerme (see also C. obtuscens in plate 1 from Van Cleave [20]), the hindtrunk seems able to become horizontally aligned with the disk without the need of a downward movement (Additional file 3: Video S1, Additional file 4: Video S2, Additional file 5: Video S3). In species with a slender hindtrunk, the ventral field of hindtrunk spines hardly reaches the anterior half (Fig. 3, and references in Aznar et al. [12]), raising the question of how they use these spines. 


\section{Ecomorphological patterns}

The interspecific variability in body morphology and muscle arrangement in Corynosoma spp. should be related, at least in part, with the specific microhabitat conditions each species experiences. Unfortunately, the physical conditions prevailing inside the gut regions of marine mammals are currently unknown and are unlikely to be elucidated in the near future. Moreover, we lack quantitative data on the gut distribution for most Corynosoma species. However, it is possible to establish coarse correlations between the morphology of Corynosoma spp. and the putative physical conditions of the microhabitats each species occupies based on a great deal of recent data on the physical processes of mammalian digestion [21].

The macroparasites attached to the gut of mammals must withstand shear forces generated by three processes, i.e. (i) mobility of gut contents; (ii) mobility of the protective mucine layer; and (iii) muscle contraction in the small intestine that causes the villi to bunch together, driving out recently secreted masses of mucin, which act in a jet-like manner [21-23]. Changes in shear forces throughout the gut depend on the pseudoplasticity and viscoelasticity of both gut contents and mucin. To date, little information on the changes of physical properties of food contents is available. In the stomach of carnivorous mammals, strong peristaltic waves move ingested food toward the narrowed pylorus so that liquids and small particles (up to $2 \mathrm{~mm}$ ) continuously flow into the duodenum, but most semi-digested food is squirted back; such retro-propulsion crush and grinds the digesta $[22,24,25]$. The fluid chyme that is sieved through the pylorus is propelled forward by peristaltic waves, but it is also subject to local mixing movements associated with wall segmentation of the small intestine [22, 23]. Absorption makes the chyme progressively change from a semi-liquid state with particulate matter that flows quickly in the duodenum, to a semi-solid viscoelastic material that flows slowly in the terminal ileum $[25,26]$. In the large intestine, segmentation and propulsion of increasingly dense contents continue [22]. From a rheological point of view, the digesta flows throughout the gut under a virtual laminar flow, i.e. at low Reynold numbers [25, 26] where frictional drag predominates, being stronger at increasing viscosity and/ or propulsion force [27].

To our knowledge, quantitative accounts on the gut distribution of Corynosoma spp. are available for just five species. Corynosoma cetaceum is exceptional among acanthocephalans in that it favours the antral part of the stomach [18], where the strongest forward-backward propulsion of semi-solid food presumably occurs. Being exposed to the strongest frictional drag, C. cetaceum exhibits not only the greatest development of Ds and VNR, but also the largest body spines of all Corynosoma species examined thus far [17]. As an interesting twist, females of C. cetaceum also have shorter bodies than males, contrary to most acanthocephalans [28], and are able to deeply fold the hindtrunk thanks to VNR contraction [29]. These features additionally reduce frictional drag, which helps females withstand the harsh microhabitat conditions in the stomach longer than males [14]. Corynosoma strumosum and C. magdaleni favour the jejunum and proximal ileum [30-32]. Rheological conditions in this microhabitat are expected to be more benign because peristaltism is less intense and the digesta more fluid than in the stomach. Additionally, flow is unidirectional and more predictable (note, however, that mucin masses associated with grouping of villi may generate additional drag). Indeed, C. strumosum and C. magdaleni are long and slender, with a modest development of Ds and VNR and just a reduced field of small spines on the ventral hindtrunk [17]. Finally, C. australe and C. semerme favour the terminal ileum and large intestine, respectively [30, 33]. Stronger directional drag is expected in these microhabitats because this is where digesta becomes semi-solid and viscous. Apparently, both species have a reduced body size to minimise exposure to frictional drag, but also cover the whole hindtrunk with long spines relative to body size to withstand it.

\section{Conclusions}

Acanthocephalus ranae is the only acanthocephalan species for which the attachment mechanism was hitherto described based on detailed observations of muscle arrangement and performance of live worms. The new evidence obtained in this study for 13 Corynosoma spp. indicates that their pipe-shaped body, which results from the ventral bending of an inflated foretrunk, brings about significant re-arrangements of foretrunk muscles. These changes, coupled with the possession of trunk spines, significantly improve the basic attachment performance described for $A$. ranae. This neat functional comparison, however, does not necessarily bear direct evolutionary implications. There is a spectacular variability of body shapes in the family Polymorphidae (hence its name), with corresponding differences of attachment function in, e.g., species of Corynosoma, Bolbosoma Porta, 1908 or Profilicollis Meyer, 1931 (see [2]). In particular, the presence of disk muscles, or the separation of two dorsal bundles and a ventral bundle, in neck retractors, are probably a plesiomorphic condition, at least in the clade of the Polymorphidae that contains Corynosoma spp. (see [12, 34]). Only a thorough analysis of anatomy and performance of acanthocephalan species within a phylogenetic framework can 
shed light on the evolution of attachment mechanisms. The comparison between $A$. ranae and Corynosoma spp., or between species of Corynosoma themselves, also illustrates how changes in attachment performance are driven by the rheological conditions each species experiences in their microhabitats. Species of Corynosoma infect carnivorous mammals with strong peristalsis and effective attachment mechanisms are therefore required to hold them in the gut [14]. Furthermore, there seems to be a coarse but clear correspondence between the efficiency of holdfast mechanisms and the specific microhabitat each species favours. Future research should provide more data on the distribution and attachment of species, as well as on the physical conditions within the gut of marine mammals.

\section{Additional files}

Additional file 1: Data S1. Morphology, performance and attachment function in Acanthocephalus ranae. (PDF 64 kb)

Additional file 2: Figure S1. Proboscis evagination mechanism in the acanthocephalan Acanthocephalus ranae (see text for details). Abbreviations: $L$, lemnisci; $N$, neck; NR, neck retractors; $P$, proboscis; PR, proboscis retractor; $R$, proboscis receptacle; $R R$, receptacle retractor. Adapted from [10] with permission of the Company of Biologists, Ltd. (PDF $85 \mathrm{~kb}$ )

Additional file 3: Video S1. Examples of evagination-invagination cycles in cystacanths of Corynosoma australe collected from the Argentine hake, Merluccius hubbsi. For scale-bar see Figs. 7 and 8. (MP4 2770 kb)

Additional file 4: Video S2. Examples of evagination-invagination cycles in cystacanths of Corynosoma australe collected from the Argentine hake, Merluccius hubbsi. For scale-bar see Figs. 7 and 8. (MP4 1919 kb)

Additional file 5: Video S3. Examples of evagination-invagination cycles in cystacanths of Corynosoma australe collected from the Argentine hake, Merluccius hubbsi. For scale-bar see Figs. 7 and 8. (MP4 14305 kb)

Additional file 6: Video S4. Ventral folding of the foretrunk in a female cystacanth of Corynosoma cetaceum collected from the flounder, Xystreurys rasile. For scale-bar see Fig. 9. (MP4 633 kb)

\section{Abbreviations}

DNR: Dorsal neck retractor muscle; DRR: Dorsal receptacle retractor muscle; Ds: Disk muscles; NR: Neck retractor muscles; PR: Proboscis retractor muscle; RR: Receptacle retractor muscle; TC: Trunk circular muscles; TL: Trunk longitudinal muscles; VNR: Ventral neck retractor muscle; VRR: Ventral receptacle retractor muscle

\section{Acknowledgements}

We are grateful to Bárbara Berón, Albert Bush, Luis Cappozzo, Enrique Crespo, Martín García-Varela, Michael Kinsella, Kristina Lehner, Scott Monks, Brent Nickol, María Soledad Sepúlveda, Allen Shostack, Tuula Sinisalo, Patricio Torres and Mijail Yurakhno for sending acanthocephalan specimens for this study. We also thank Roger G. Lentle for his thoughtful comments on the physical features of mammalian digestion. Photographs with SEM were made thanks to the SCSIE of the University of Valencia, Spain. Additional file 2: Figure S1 was adapted from figure 3 of Hammond [10] with permission from The Company of Biologists, Ltd.

\section{Funding}

Supported by projects PROMETEOII/2015/018 from the Generalitat Valenciana, CGL2007-63221 of the Ministry of Education and Science (MEC) of Spain, and AGL2015/68405/R from MINECO-FEDER, Spain.

\section{Availability of data and materials}

Data supporting the conclusions of this article are included within the article and its additional files. Raw data and specimens examined are available from the corresponding author upon request.

\section{Authors' contributions}

FJA conceived the study. FJA, JSH-O and JAR obtained the samples. FJA and JSH-O performed the analyses. FJA, JSH-O and JAR drafted and revised the manuscript. All authors read and approved the final manuscript.

\section{Ethics approval}

All applicable institutional, national and international guidelines for the care and use of animals were followed.

\section{Consent for publication}

Not applicable.

\section{Competing interests}

The authors declare that they have no competing interests.

\section{Publisher's Note}

Springer Nature remains neutral with regard to jurisdictional claims in published maps and institutional affiliations.

\section{Author details}

${ }^{1}$ Instituto Cavanilles de Biodiversidad y Biología Evolutiva, Parque Científico, Universidad de Valencia, Catedrático José Beltrán 2, 46980, Paterna, Valencia, España. ${ }^{2}$ Centro de Investigación Aplicada y Transferencia Tecnológica en Recursos Marinos Almirante Storni (CIMAS - CCT CONICET - CENPAT), Güemes 1030, 8520 San Antonio Oeste, Río Negro, Argentina.

Received: 17 July 2018 Accepted: 22 October 2018

Published online: 13 December 2018

\section{References}

1. Taraschewski H. Host-parasite interactions in Acanthocephala: a morphological approach. Adv Parasitol. 2000;46:1-179.

2. Van Cleave HJ. Some host-parasite relationships of the Acanthocephala, with special reference to the organs of attachment. Exp Parasitol. 1952; 1:305-30.

3. Aznar FJ, Bush AO, Fernández M, Raga JA. Constructional morphology and mode of attachment of the trunk of Corynosoma cetaceum (Acanthocephala: Polymorphidae). J Morphol. 1999:241:237-49.

4. Herlyn $\mathrm{H}$, Ehlers U. Organisation of the praesoma in Acanthocephalus anguillae (Acanthocephala, Palaeacanthocephala) with special reference to the muscular system. Zoomorphology. 2001;121:13-8.

5. Herlyn $\mathrm{H}$. The musculature of the praesoma in Macracanthorhynchus hirudinaceus (Acanthocephala, Archiacanthocephala): re-examination and phylogenetic significance. Zoomorphology. 2002;121:173-82.

6. Herlyn $\mathrm{H}$, Taraschewski $\mathrm{H}$. Evolutionary anatomy of the muscular apparatus involved in the anchoring of Acanthocephala to the intestinal wall of their vertebrate hosts. Parasitol Res. 2017;116:1207-25.

7. Arnold SJ. Morphology, performance and fitness. Am Zool. 1983;23:347-61.

8. Koehl MAR. When does morphology matter? Annu Rev Ecol Syst. 1996; 27:501-42.

9. Hammond RA. Changes of internal hydrostatic pressure and body shape in Acanthocephalus ranae. J Exp Biol. 1966;45:197-202.

10. Hammond RA. The proboscis mechanism of Acanthocephalus ranae. J Exp Biol. 1966;45:203-13

11. Hammond RA. The mode of attachment within the host of Acanthocephalus ranae (Schrank, 1788), Lühe, 1911. J Helminthol. 1967;41:321-8.

12. Aznar FJ, Pérez-Ponce de León G, Raga JA. Status of Corynosoma (Acanthocephala: Polymorphidae) based on anatomical, ecological, and phylogenetic evidence, with the erection of Pseudocorynosoma n. gen. J Parasitol. 2006:92:548-64

13. Waindok P, Lehnert K, Siebert U, Pawliczka I, Strube C. Prevalence and molecular characterisation of Acanthocephala in pinnipedia of the North and Baltic Seas. Int J Parasitol Parasites Wildl. 2018;7:34-43.

14. Hernández-Orts JS, Timi JT, Raga JA, García-Varela M, Crespo EA, Aznar FJ. Patterns of trunk spine growth in two congeneric species of 
acanthocephalan: investment in attachment may differ between sexes and species. Parasitology. 2012;139:945-55.

15. Amin OM, Heckmann RA, Halajian A, El-Naggar AM. The morphology of an unique population of Corynosoma strumosum (Acanthocephala, Polymorphidae) from the Caspian seal, Pusa caspica, in the land-locked Caspian Sea using SEM, with special notes on histopathology. Acta Parasitol. 2011;56:438-45.

16. Silva RZ, Pereira J Jr, Cousin JC. Histological patterns of the intestinal attachment of Corynosoma australe (Acanthocephala: Polymorphidae) in Arctocephalus australis (Mammalia: Pinnipedia). J Parasit Dis. 2014;38:410-6.

17. Aznar FJ, Crespo EA, Raga JA, Hernández-Orts JS. Trunk spines in cystacanths and adults of Corynosoma spp. (Acanthocephala): Corynosoma cetaceum as an exceptional case of phenotypic variability. Zoomorphology. 2016;135:19-31.

18. Aznar FJ, Bush AO, Balbuena JA, Raga JA. Corynosoma cetaceum in the stomach of franciscanas, Pontoporia blainvillei (Cetacea): an exceptional case of habitat selection by an acanthocephalan. J Parasitol. 2001:87:536-41.

19. Ionita M, Varela MG, Lyons ET, Spraker TR, Tolliver SC. Hookworms (Uncinaria lucasi) and acanthocephalans (Corynosoma spp. and Bolbosoma spp.) found in dead northern fur seals (Callorhinus ursinus) on St. Paul Island, Alaska in 2007. Parasitol Res. 2008;103:1025-9.

20. Van Cleave HJ. A preliminary analysis of the acanthocephalan genus Corynosoma in mammals of North America. J Parasitol. 1953;39(1):13.

21. Lentle RG, Janssen PWM. The Physical Processes of Digestion. New York: Springer-Verlag; 2011.

22. Bornhorst GM, Singh RP. Gastric digestion in vivo and in vitro: how the structural aspects of food influence the digestion process. Annu Rev Food Sci Technol. 2014:5:111-32.

23. Lentle $R G$, de Loubens $C$. A review of mixing and propulsion of chyme in the small intestine: fresh insights from new methods. J Comp Physiol B. 2015;185:369-87.

24. Kong F, Singh RP. Disintegration of solid foods in human stomach. J Food Sci. 2008;73:R67-80.

25. Takahashi T. Flow behavior of digesta and the absorption of nutrients in the gastrointestine. J Nutr Sci Vitaminol. 2011;57:265-73.

26. Lentle RG, de Loubens C. Physical characteristics of digesta and their influence on flow and mixing in the mammalian intestine: a review. J Comp Physiol B. 2008;178:673-90.

27. Vogel S. Life in Moving Fluids: The Physical Biology of Flow. Princeton: Princeton University Press; 1994.

28. Aznar FJ. Estudio biológico de la helmintofauna de la Franciscana (Pontoporia blainvillei) (Cetacea) en aguas de Argentina. PhD Thesis. Valencia: Universitat de València; 1995.

29. Aznar FJ, Bush AO, Raga JA. Reduction and variability of trunk spines in the acanthocephalan Corynosoma cetaceum: the role of physical constraints on attachment. Invertebr Biol. 2002:121:104-14.

30. Nickol BB, Helle E, Valtonen ET. Corynosoma magdaleni in grey seals from the Gulf of Bothnia, with emended descriptions of Corynosoma strumosum and Corynosoma magdaleni. J Parasitol. 2002;88:1222-9.

31. Sinisalo T, Kunnasranta M, Valtonen ET. Intestinal helminths of a landlocked ringed seal (Phoca hispida saimensis) population in eastern Finland. Parasitol Res. 2003;91:40-5.

32. Kaimoto T, Hirazawa T, Masubuchi T, Morohoshi A, Katahira H, Kobayashi M. Host characteristics and infection level of an intestinal parasite Conynosoma strumosum (Acanthocephala) in the Kuril harbor seal of Erimo Cape, Hokkaido, Japan. Parasitol Int. 2018;67:237-44.

33. Aznar FJ, Cappozzo HL, Taddeo D, Montero FE, Raga JA. Recruitment, population structure, and habitat selection of Corynosoma australe (Acanthocephala) in South American fur seals, Arctocephalus australis, from Uruguay. Can J Zool. 2004;82:726-33.

34. García-Varela M, de León GP-P, Aznar FJ, Nadler SA. Phylogenetic relationship among genera of Polymorphidae (Acanthocephala), inferred from nuclear and mitochondrial gene sequences. Mol Phyl Evol. 2013;68: $176-84$.

Ready to submit your research? Choose BMC and benefit from:

- fast, convenient online submission

- thorough peer review by experienced researchers in your field

- rapid publication on acceptance

- support for research data, including large and complex data types

- gold Open Access which fosters wider collaboration and increased citations

- maximum visibility for your research: over $100 \mathrm{M}$ website views per year

At BMC, research is always in progress.

Learn more biomedcentral.com/submissions 